\title{
OPTIMASI PEMANFAATAN SUMBER DAYA UDANG DOGOL (Metapenaeus ensis de Haan) DI PERAIRAN CILACAP DAN SEKITARNYA
}

\author{
Ali Suman*
}

\begin{abstract}
ABSTRAK
Penelitian yang dilakukan bertujuan untuk menentukan strategi pemanfaatan sumber daya udang dogol (Metapenaeus ensis de Haan) secara optimal di perairan Cilacap dan sekitarnya, yang dilaksanakan dari Desember 2002 sampai dengan Juni 2003. Metode yang digunakan adalah model optimasi program linear untuk menentukan kombinasi unit penangkapan yang optimal. Hasil penelitian menunjukkan kombinasi unit penangkapan optimal adalah dengan mengoperasikan 3.813 unit alat tangkap trammel net pasif dengan keuntungan yang diperoleh sebesar Rp. 47,9 milyar per tahun serta membuka peluang investasi pengembangan sekitar 1.025 unit alat tangkap trammel net pasif. Penerapan strategi ini juga dapat mengintegrasikan aspek ekonomi dan sosial sebagai dimensi dari perikanan yang berkelanjutan.
\end{abstract}

\section{ABSTRACT: Exploitation optimization of endeavour shrimp resources in Cilacap and adjacent waters. By: Ali Suman}

The current research aims to determine a strategy for the optimal exploitation of endeavour shrimp resources (M. ensis de Haan) in Cilacap and its adjacent waters. This research was conducted from December 2002 to June 2003. The evaluation was based on optimization model of linear programming for the determination of optimal combination fishing units. The results show that the strategy for optimum exploitation of endeavour shrimp in Cilacap and adjacent waters is restricted on 3.813 units of effort of passive trammel net with profit Rp. 47.9 billion per year and opportunity for development investment is 1.025 units of passive trammel net. Application of this strategy will integrate social and economic aspects as sustainable fishery dimension.

KEYWORDS: $\quad$ exploitation, optimation, Metapenaeus ensis, Cilacap water

\section{PENDAHULUAN}

Perairan Cilacap dan sekitarnya merupakan salah satu daerah penangkapan udang dogol yang cukup potensial di Indonesia. Produksi udang di perairan ini didominasi oleh udang dogol sekitar $51 \%$ (Suman, 2003). Pemanfaatan sumber daya udang dogol di perairan ini sudah lama dilakukan, tetapi secara komersil baru di mulai pada tahun 1966, dengan mulai berkembangnya perikanan trawl untuk menangkap udang di perairan ini (Naamin, 1972, Gunadi, 1981). Sejak saat itu perkembangan pemanfaatan udang di perairan ini sangat intensif dan meningkat setiap tahun akibat bertambahnya armada penangkapan dan angkatan kerja (Van Zalinge \& Naamin, 1975; Naamin, 1978).

Walaupun udang termasuk sumber daya yang dapat pulih (renewable resources) tetapi penangkapan yang terus meningkat tanpa adanya pembatasan akan menyebabkan degradasi sumber daya tersebut. Mengingat tingginya intensitas penangkapan udang dogol (Metapenaeus ensis de Haan) di perairan Cilacap, yang dilakukan setiap hari sepanjang tahun, dikhawatirkan pemanfaatannya akan mengancam kelestarian dan keberlanjutan pemanfaatan sumber daya udang dogol di perairan ini. Hal ini telah terindikasi dengan terjadinya penurunan produksi dalam kurun waktu 13 tahun terakhir (Suman, 2003), di lain pihak terjadi kenaikan jumlah upaya penangkapan. Dengan demikian apabila kondisi pemanfaatan yang ada saat ini tetap berjalan, maka diduga dalam jangka panjang akan dapat menyebabkan sumber daya udang dogol di perairan Cilacap dan sekitarnya terancam kelestariannya.

Melihat fenomena tersebut, di perairan Cilacap dan sekitarnya hendaknya dilakukan upaya-upaya pengelolaan pemanfaatan sumber daya udang dogol yang lebih baik, sehingga sumber daya udang dogol yang ada masih dapat menjadi modal bagi perbaikan (recovery) stok dalam kaitan pemanfaatannya secara berkelanjutan. Tulisan ini akan membahas tentang optimasi pemanfaatan sumber daya udang dogol di perairan Cilacap dan diharapkan dapat digunakan sebagai bahan masukan untuk tujuan pengelolaan dan dasar bagi pengkajian selanjutnya.

\section{BAHAN DAN METODE}

Penelitian ini dilakukan dari bulan Desember 2002 sampai dengan Juni 2003 di perairan Cilacap dan sekitarnya (Gambar 1). Penelitian dilakukan dengan pengamatan langsung di pusat-pusat pendaratan udang di perairan Cilacap dan sekitarnya (PPSC, TPI Sidakaya, TPI Argopeni, TPI Pangandaran). Seluruh pengumpulan data untuk keperluan pengkajian ini dilakukaan dengan metode survei.

\footnotetext{
"Peneliti pada Balai Riset Perikanan Laut, Jakarta
} 


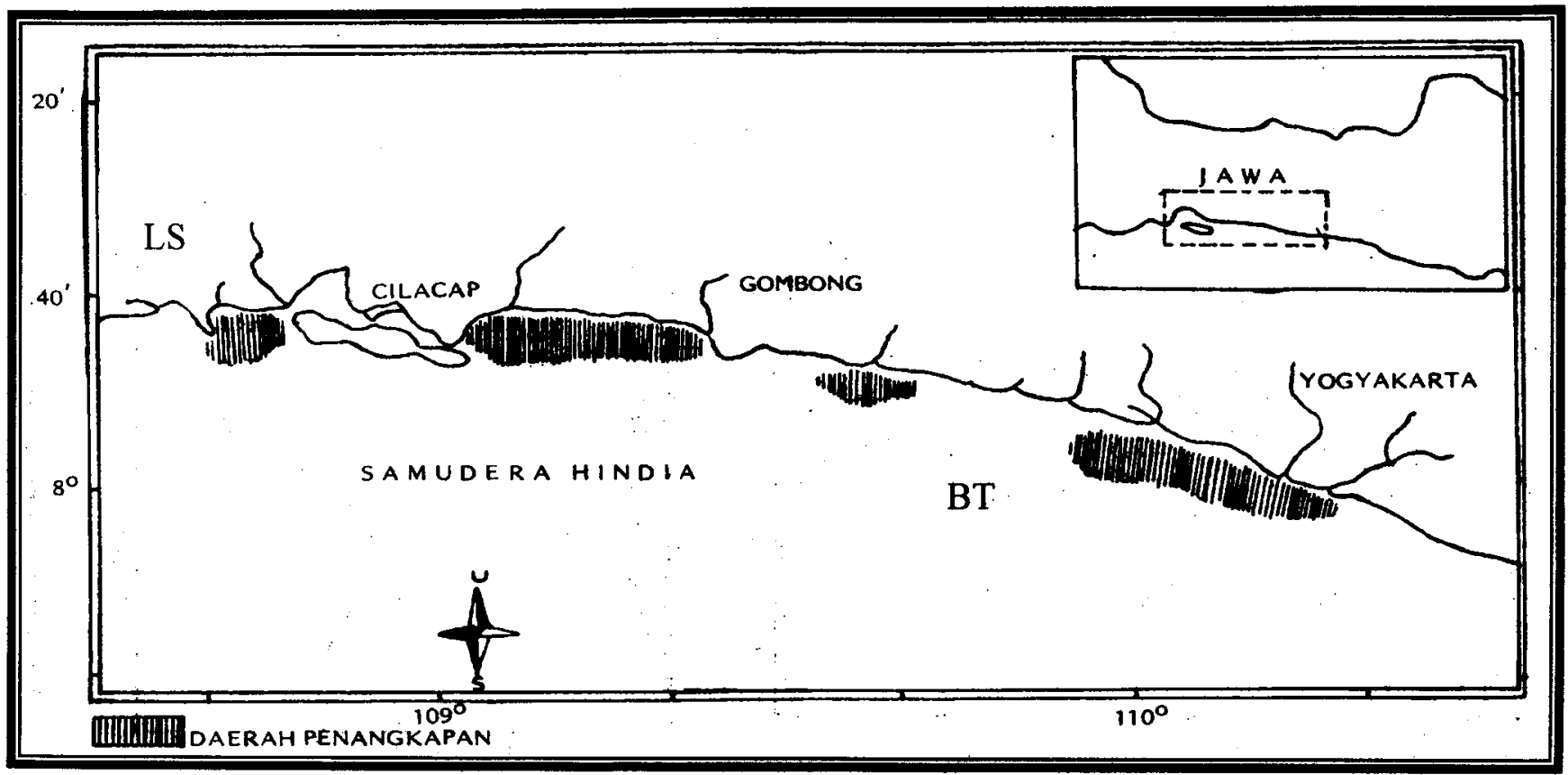

Gambar 1. Daerah penangkapan udang dogol di Perairan Cilacap dan sekitarnya.

Figure 1. Fishing ground in Cilacap and adjacent waters.

Analisis data untuk optimasi digunakan model program linier (Supranto, 1988; Soekartawi, 1995) dengan menggunakan software bahasa pemrograman LINDO. Karena model regresi yang akan digunakan dalam penelitian ini bersifat linear dan dengan kondisi batasan (kendala) yang tidak boleh dilampaui maka model optimasi yang di pilih adalah model optimasi berkendala.

Fungsi tujuan dari pengkajian ini adalah memaksimumkan keuntungan:

$$
Z=C j . X j
$$

Terhadap fungsi kendala:

$a 11 \times 1+a 12 \times 2+\ldots+a 1 n \times n \leq b 1$

$a 21 \times 1+a 22 \times 2+\ldots .+a 2 n \times n \leq b 2$

$a m 11 \times 1+a m 2 \times 2+\ldots .+a m n \times n \leq b m$

Adapun $X$ adalah variabel putusan ke-j, $C$ adalah parameter fungsi tujuan $k e-j, b$ adalah kapasitas kendala ke-i, aij adalah parameter fungsi kendala ke- $i$ dan variabel keputusan ke-j, $i$ adalah $1,2,3, \ldots . . . m, j$ adalah $1,2,3, \ldots . . n$ serta $e j$ adalah galat baku.

Elemen-elemen yang digunakan dalam model ini terdiri dari: (1) fungsi tujuan, yaitu nilai keuntungan maksimum dari usaha penangkapan udang, (2) fungsi pembatas, yaitu nilai hasil tangkapan maksimum (CMSY) dan upaya penangkapan maksimum (EMSY) dan (3) koefisien input-output, yaitu nilai keuntungan tiap jenis alat tangkap, nilai hasil tangkapan per unit upaya penangkapan (CPUE) per alat tangkap dan indeks daya tangkap (FPI) per alat tangkap.

\section{Fungsi Tujuan}

Fungsi tujuan dari penelitian ini adalah memaksimumkan keuntungan usaha penangkapan udang dogol. Karena ada sejumlah alat tangkap yang dioperasikan di perairan sekitarnya, maka fungsi tujuan tersebut adalah:

$$
\pi=\Sigma(T R-T C)
$$

Karena satu jenis alat tangkap dapat menangkap lebih dari satu jenis udang maka fungsi tujuan menjadi:

$$
\pi=\sum_{i=1}^{n} \sum_{j=1}^{n} i(Y i j . v j)-\sum_{j=1}^{n} \text { cj.vj }
$$

atau

$$
\pi=\sum_{i=1}^{n} \varphi j \cdot v j
$$

Adapun pi adalah harga udang jenis $i$, Yij adalah produktivitas alat tangkap $j$ terhadap udang $l$ (CPUEI), $v j$ adalah jumlah jenis alat tangkap $j$, $c j$ adalah biaya operasional armada-armada penangkapan $j$ per tahun serta $\varphi j$ adalah nilai keuntungan masing-masing alat dalam setahun.

\section{Fungsi Pembatas}

Dalam melakukan pengelolaan dan pemanfaatan sumber daya perikanan (udang), jumlah hasil tangkapan dan upaya penangkapan biasanya 
didasarkan pada nilai optimum hasil tangkapan dan upaya penangkapan yang digunakan atau sering di sebut sebagai nilai maximum sustainable yield (MSY). Pemanfaatan akan lestari dan berkelanjutan apabila hasil tangkapan maksimum mencapai nilai MSY. Berdasarkan hal tersebut, maka dalam pengkajian ini nilai-nilai upaya penangkapan (EMSY) dan nilai hasil tangkapan (CMSY) pada kondisi MSY dijadikan sebagai faktor pembatas yang tidak boleh dilampaui dalam pemanfaatan sumber daya udang.

\section{Hasil Tangkapan Lestari (CMSY)}

Suatu jenis udang di daerah tropis seperti Indonesia dapat ditangkap oleh lebih dari satu jenis alat tangkap, sehingga penggabungan hasil tangkapan dari beberapa jenis alat tangkap udang harus $\leq$ CMSY

$n n$

$\sum \sum(Y i j . v j) \leq C M S Y(i)$

$\sum_{i=1} \sum_{j=1}$

Adapun $Y i j$ adalah produktivitas alat tangkap $j$ terhadap udang $i$ (CPUEij), vj adalah jumlah jenis alat tangkap $j$ dan $C M S Y(I)$ adalah hasil tangkapan maksimum yang lestari.

\section{Upaya Penangkapan Lestari (EMSY)}

Upaya penangkapan optimum yang diperoleh berdasarkan perhitungan model surplus produksi adalah merupakan upaya penangkapan standar yang disusun atas beberapa jenis alat tangkap udang, sehingga jumlah upaya penangkapan udang dari masing-masing jenis alat tangkap udang harus diketahui. Untuk mendapatkan upaya penangkapan per jenis alat tangkap terhadap suatu jenis udang maka perlu dilakukan perhitungan sebagai berikut:

$\sum_{i=1}^{n} \sum_{j=1}^{n}(F P(i j . v j) \leq C M S Y(i)$

Tabel 1. Perkembangan alat tangkap udang dogol (unit) di perairan Cilacap dan sekitarnya

Table 1. Development of fishing gear of endeavour shrimp (unit) in Cilacap waters

\begin{tabular}{cccccrrrr}
\hline \multirow{2}{*}{$\begin{array}{c}\text { Tahun } \\
\text { Year }\end{array}$} & \multicolumn{2}{c}{ Cilacap } & \multicolumn{2}{c}{ Ciamis } & \multicolumn{2}{c}{ Kebumen } & \multicolumn{1}{c}{ Total } \\
\cline { 2 - 9 } & TN & JD & TN & JD & TN & JD & TN & JD \\
\hline 1990 & 629 & - & 388 & 135 & 194 & - & 1.221 \\
1991 & 408 & - & 258 & 142 & 31 & - & 967 & 142 \\
1992 & 650 & - & 280 & 142 & 137 & - & 1.067 & 142 \\
1993 & 293 & - & 273 & 142 & 80 & - & 646 & 142 \\
1994 & 889 & - & 304 & 140 & 180 & - & 1.373 & 140 \\
1995 & 895 & - & 343 & 143 & 196 & - & 1.434 & 143 \\
1996 & 904 & - & 240 & 98 & 104 & - & 1.248 & 98 \\
1997 & 399 & - & 338 & 21 & 95 & - & 832 & 21 \\
1998 & 399 & - & 559 & 21 & 323 & - & 1.281 & 21 \\
1999 & 595 & - & 559 & 33 & 318 & - & 1.472 & 33 \\
2000 & 595 & - & 559 & 195 & 319 & - & 1.473 & 195 \\
2001 & 595 & - & 661 & 195 & 503 & - & 1.759 & 195 \\
2002 & 595 & - & 661 & 195 & 321 & - & 1.577 & 195 \\
\hline
\end{tabular}

Adapun FPlij adalah daya tangkap alat tangkap $j$ terhadap jenis udang $i, v j$ adalah jumlah jenis alat tangkap $j$ dan EMSY $(i)$ adalah upaya penangkapan maksimum lestari.

\section{HASIL DAN BAHASAN}

\section{Aspek Penangkapan Udang Dogol}

Pemanfaatan udang dogol di perairan Cilacap dan sekitarnya sudah berlangsung cukup lama dan secara terdapatnya alat tangkap jaring arad sebanyak 82 unit dan jaring klitik sebanyak 30 unit untuk menangkap udang (Naamin, 1972). Pemanfaatan ini kemudian berkembang secara pesat setelah diperkenalkannya trawl menjadi alat tangkap utama udang dogol di perairan ini. Pada tahun 1971 telah tercatat sekitar 13 armada trawl yang beroperasi di perairan Cilacap dan sekitarnya dan terus melonjak menjadi 368 armada pada tahun 1974, namun kemudian terus menurun menjadi 89 armada pada tahun 1980 (Naamin, 1978; Gunadi, 1981). Perkembangan yang begitu cepat dan cenderung tidak terkendali dari perikanan trawl di perairan ini mengakibatkan terjadinya konflik sosial antara nelayan tradisional dan nelayan trawl yang mengakibatkan terjadinya pembakaran armada trawl. Konflik ini terus meluas dan akhirnya diredam dengan dikeluarkannya KEPPRES No.39 tahun 1980 yaitu tentang pelarangan penggunaan alat tangkap trawl di perairan Indonesia. Setelah penghapusan alat tangkap trawl di perairan Cilacap dan sekitarnya, maka yang menjadi alat tangkap utama udang dogol adalah trammel net. Selain itu masih terdapat alat tangkap udang dogol yang beroperasi yaitu alat tangkap jaring dogol di perairan Ciamis. Pada Tabel 1 disajikan perkembangan alat tangkap udang dogol di perairan Cilacap dan sekitarnya.

Trammel net yang dioperasikan di perairan Cilacap dan sekitarnya secara garis besar digolongkan statistik mulai tercatat sejak tahun 1966 dengan

Keterangan/Remarks: TN: trammel net, JD: Jaring Dogol 
menjadi dua jenis menurut cara pengoperasiannya yaitu (1) jaring di tarik menyapu (sweeping) di dasar perairan (trammel net aktif) dan (2) jaring dihanyutkan di atas dasar perairan (trammel net pasif). Trammel net yang dioperasikan secara aktif dilakukan oleh nelayan wilayah Cilacap, sedangkan secara pasif dilakukan oleh nelayan di wilayah Kebumen dan Ciamis. Secara rinci deskripsi alat tangkap trammel net disajikan pada Tabel 2.

Satu trip penangkapan trammel net pasif berlangsung selama satu hari yaitu dari pagi sampai siang (pukul 04.00-15.00 WIB), sedangkan satu trip penangkapan trammel net aktif terdapat dua macam yaitu trip harian (pukul 04.00-16.00 WIB) dan trip mingguan ( 7 hari). Trammel net pasif dioperasikan dengan menggunakan perahu berukuran panjang 9 $\mathrm{m}$, lebar $0,80 \mathrm{~m}$, dan dalam $0,70 \mathrm{~m}$. Trammel net aktif trip harian dalam operasinya menggunakan perahu dengan panjang $9 \mathrm{~m}$, lebar $1 \mathrm{~m}$, dan dalam $0,80 \mathrm{~m}$, sementara itu operasional trammel net aktif trip mingguan menggunakan perahu dengan panjang 15 $\mathrm{m}$, lebar $4 \mathrm{~m}$, dan dalam $3 \mathrm{~m}$. Tenaga penggerak trammel net pasif berupa motor tempel (bahan bakar

Tabel 2. Deskripsi trammel net di perairan Cilacap dan sekitarnya

Table 2. Description of trammel net in Cilacap and adjacent waters

\begin{tabular}{|c|c|c|c|}
\hline \multirow{2}{*}{ Bagan } & \multicolumn{3}{|c|}{ Wilayah } \\
\hline & Cilacap & Kebumen & Ciamis \\
\hline $\begin{array}{l}\text { Jaring: } \\
\text { - Lapis luar } \\
\text { Bahan } \\
\text { Nomor benang } \\
\text { Ukuran mata jaring } \\
\text { Panjang jaring (mata) } \\
\text { Dalam jaring (mata) } \\
\text { Panjang terpasang: - atas } \\
\text { - bawah } \\
\end{array}$ & $\begin{array}{l}\text { Nylon (PA) } \\
210 \mathrm{~d} / 6 \\
150 \mathrm{~mm} \\
346 \text { mata } \\
9 \text { mata } \\
40 \mathrm{~m} \\
45 \mathrm{~m}\end{array}$ & $\begin{array}{l}\text { Nylon (PA) } \\
210 \mathrm{~d} / 6 \\
175 \mathrm{~mm} \\
224 \text { mata } \\
9 \text { mata } \\
18 \mathrm{~m} \\
22 \mathrm{~m} \\
\end{array}$ & $\begin{array}{l}\text { Nylon (PA) } \\
210 \mathrm{~d} / 9 \\
135 \mathrm{~mm} \\
237 \text { mata } \\
9 \text { mata } \\
36 \mathrm{~m} \\
38 \mathrm{~m} \\
\end{array}$ \\
\hline $\begin{array}{l}\text { Lapis dalam } \\
\text { Bahan } \\
\text { Nomor benang } \\
\text { Ukuran mata jaring } \\
\text { Panjang jaring (mata) } \\
\text { Dalam jaring (mata) } \\
\text { Pengerutan: - atas } \\
\quad \text { - bawah } \\
\text { Panjang terpasang: - atas } \\
\text { - bawah }\end{array}$ & $\begin{array}{l}\text { Nylon (PA) } \\
210 \mathrm{~d} / 3 \\
48 \mathrm{~mm} \\
1.700 \mathrm{mata} \\
50 \mathrm{mata} \\
0,55 \mathrm{~m} \\
0,48 \mathrm{~m} \\
40 \mathrm{~m} \\
45 \mathrm{~m}\end{array}$ & $\begin{array}{l}\text { Nylon (PA) } \\
210 \mathrm{~d} / 3 \\
38 \mathrm{~mm} \\
874 \mathrm{mata} \\
40 \mathrm{mata} \\
0,55 \mathrm{~m} \\
0,48 \mathrm{~m} \\
18 \mathrm{~m} \\
22 \mathrm{~m}\end{array}$ & $\begin{array}{l}\text { Nylon (PA) } \\
210 \mathrm{~d} / 3 \\
35 \mathrm{~mm} \\
915 \mathrm{mata} \\
43 \mathrm{mata} \\
0,55 \mathrm{~m} \\
0,48 \mathrm{~m} \\
36 \mathrm{~m} \\
38 \mathrm{~m}\end{array}$ \\
\hline $\begin{array}{l}\text { Srampat } \\
\text { Bahan/diameter } \\
\text { Ukuran mata } \\
\text { Panjang: - atas } \\
\quad \text { - bawah } \\
\text { Panjang terpasang: - atas } \\
\text { - bawah }\end{array}$ & $\begin{array}{l}P E / 1 \mathrm{~mm} \\
61 \mathrm{~mm} \\
40 \mathrm{~mm} \\
45 \mathrm{~mm} \\
2 \text { mata } \\
2 \text { mata }\end{array}$ & $\begin{array}{l}P E / 1 \mathrm{~mm} \\
61 \mathrm{~mm} \\
40 \mathrm{~mm} \\
45 \mathrm{~mm} \\
2 \text { mata } \\
2 \text { mata }\end{array}$ & $\begin{array}{l}P E / 1 \mathrm{~mm} \\
61 \mathrm{~mm} \\
40 \mathrm{~mm} \\
45 \mathrm{~mm} \\
2 \mathrm{mata} \\
2 \text { mata }\end{array}$ \\
\hline $\begin{array}{l}\text { Tali temali } \\
\text { - Ris atas } \\
\text { Bahan } \\
\text { Diameter } \\
\text { Panjang } \\
\text { - Tali pelampung } \\
\text { Bahan } \\
\text { Diameter } \\
\text { Panjang } \\
\text { - Ris bawah } \\
\text { Bahan } \\
\text { Diameter } \\
\text { Panjang } \\
\text { - Tali pemberat } \\
\text { Bahan } \\
\text { Diameter } \\
\text { Panjang }\end{array}$ & $\begin{array}{l}\text { PE } \\
4 \mathrm{~mm} \\
40 \mathrm{~mm} \\
P E \\
3 \mathrm{~mm} \\
40 \mathrm{~mm} \\
\text { PE } \\
3 \mathrm{~mm} \\
45 \mathrm{~mm} \\
P E \\
3 \mathrm{~mm} \\
45 \mathrm{~mm}\end{array}$ & $\begin{array}{l}\text { PE } \\
5 \mathrm{~mm} \\
18 \mathrm{~mm} \\
P E \\
4 \mathrm{~mm} \\
18 \mathrm{~mm} \\
P E \\
4 \mathrm{~mm} \\
22 \mathrm{~mm} \\
P E \\
4 \mathrm{~mm} \\
22 \mathrm{~mm}\end{array}$ & $\begin{array}{l}\text { PE } \\
5 \mathrm{~mm} \\
36 \mathrm{~mm} \\
P E \\
4 \mathrm{~mm} \\
36 \mathrm{~mm} \\
P E \\
3 \mathrm{~mm} \\
38 \mathrm{~mm} \\
P E \\
3 \mathrm{~mm} \\
38 \mathrm{~mm}\end{array}$ \\
\hline
\end{tabular}


bensin) berkekuatan 10-15 PK, sedang trammel net aktif trip harian menggunakan motor tempel (bahan bakar solar) yang berkekuatan 15-25 PK dan trammel net aktif trip mingguan tenaga penggeraknya menggunakan motor dalam berbahan bakar solar dengan kekuatan 30-125 PK. Jumlah ABK alat tangkap trammel net pasif terdiri dari 2 orang, sedang $A B K$ alat tangkap trammel net aktif trip harian meliputi 4 orang dan $A B K$ alat tangkap trammel net aktif trip mingguan terdiri dari 7 orang. Cara operasi trammel net pasif dilakukan dengan menebar dan membiarkan jaring selama 1,50 jam di dasar perairan, kemudian baru di angkat dan penaburan ini dilakukan sebanyak 6 kali dalam satu trip. Trammel net aktif trip harian dioperasikan dengan menarik jaring sekitar 1,50 jam satu kali tawur dan dilakukan tiga kali tawur dalam satu trip, sedangkan pada trammel net aktif trip mingguan penarikan dilakukan selama dua jam sekali penurunan jaring dan dilakukan 4 kali dalam satu hari.

Dalam satu perahu trammel net pasif terdiri dari 18 tingting, sedang satu perahu trammel net aktif trip harian meliputi 20 tingting dan trammel net aktif trip mingguan satu armada membawa 50 tingting.

Sementara itu alat tangkap udang dogol lainnya adalah jaring dogol yang merupakan alat tangkap yang hanya terdapat di perairan Pangandaran (Ciamis). Konstruksi utama alat tangkap dogol terdiri atas bagian sayap (wing), bagian badan (body) dan kantong (cod end). Secara rinci deskripsi alat tangkap jaring dogol diterapkan pada Tabel 3.

Tabel 3. Deskripsi jaring dogol di perairan Cilacap dan sekitarnya

Table 3. Description of dogol net in Cilacap and adjacent waters

\begin{tabular}{|c|c|}
\hline Bagan & Ukuran \\
\hline $\begin{array}{l}\text { Jaring: } \\
\text { - Sayap jaring } \\
\text { Bahan } \\
\text { Ukuran mata } \\
\text { Panjang } \\
\text { Badan jaring } \\
\text { Bahan } \\
\text { Ukuran mata jaring } \\
\text { Panjang } \\
\text { Kantong jaring } \\
\text { Bahan } \\
\text { Ukuran mata jaring } \\
\text { Panjang }\end{array}$ & $\begin{array}{c}\text { PE diameter } 1,0 \mathrm{~mm} \\
3,5 \mathrm{~cm} \\
40 \mathrm{~m} \\
\text { PE diameter } 1,0 \mathrm{~mm} \\
3,0 \mathrm{~cm} \\
4,95 \mathrm{~m} \\
\text { PE diameter } 1,2 \mathrm{~mm} \\
2,5 \mathrm{~cm} \\
0,83 \mathrm{~m}\end{array}$ \\
\hline $\begin{array}{l}\text { Tali temali } \\
\text { - Ris atas (head rope) } \\
\text { Bahan } \\
\text { Panjang } \\
\text { - Ris bawah (ground rope) } \\
\text { Bahan } \\
\text { Panjang } \\
\text { - Tali slambar (warp) } \\
\text { Bahan } \\
\text { Panjang }\end{array}$ & $\begin{array}{c}\text { PE diameter } 3 \mathrm{~mm} \\
41 \mathrm{~m} \\
\text { PE diameter } 3 \mathrm{~mm} \\
41 \mathrm{~m}\end{array}$ \\
\hline $\begin{array}{l}\text { Pelampung } \\
\text { Bahan } \\
\text { Bentuk } \\
\text { Jumlah } \\
\text { Pemberat } \\
\text { Bahan } \\
\text { Ukuran } \\
\text { Jumlah }\end{array}$ & $\begin{array}{c}\text { Gabus } \\
\text { Bulat lonjong } \\
25 \text { buah } \\
\text { batu } \\
\text { diameter } 15 \mathrm{~mm} \\
20 \text { buah }\end{array}$ \\
\hline
\end{tabular}

Jaring dogol yang dioperasikan oleh nelayan Pangandaran adalah merupakan modifikasi dari jaring arad yang cara pengoperasiannya tidak lagi di tarik ke daratan (pantai), tetapi dengan tali panjang (warp) di tarik menelusuri dasar perairan ke arah perahu yang dalam keadaan berhenti dan dalam satu trip dilakukan 16 kali penurunan jaring.
Satu trip penangkapan jaring dogol berlangsung selama satu hari yaitu dari pagi sampai siang (pukul 05.00-14.00 WIB). Alat tangkap jaring dogol dioperasikan dengan menggunakan perahu berukuran panjang $9 \mathrm{~m}$, lebar $1,10 \mathrm{~m}$, dan dalam $0,80 \mathrm{~m}$ dan dilengkapi dengan katir (cadik) sebagai penyeimbang perahu. Tenaga penggerak alat tangkap jaring dogol 
berupa motor tempel (bahan bakar bensin) berkekuatan 15 PK serta jumlah ABK alat tangkap jaring dogol ini terdiri dari 4 orang.

Wilayah yang menjadi penangkapan udang dogol di perairan Cilacap dan sekitarnya meliputi wilayah Kabupaten Ciamis, Cilacap, Kebumen sampai selatan Yogyakarta yaitu pada kedalaman sekitar 5-40 m. Daerah yang menjadi pusat penangkapan dan pendaratan udang dogol hanya terpusat di Ciamis, Cilacap, dan Kebumen serta kontribusi pendaratan yang terbesar adalah Kabupaten Cilacap. Hal ini berkaitan dengan keterampilan dan mobilitas penangkapan nelayan Cilacap dengan armada yang lebih besar yang menjangkau seluruh wilayah penangkapan mulai dari perairan Ciamis sampai dengan selatan Yogyakarta, sementara itu nelayan Ciamis dan Kebumen daerah penangkapan nelayannya hanya terbatas di sekitar wilayahnya.

\section{Optimasi Pemanfaatan}

Optimasi pemanfaatan sumber daya udang dogol yang dilakukan di perairan Cilacap dan sekitarnya dimaksudkan untuk mencari nilai optimum masingmasing alat tangkap udang dogol yang dioperasikan di perairan Cilacap dan sekitarnya sehingga mendapatkan nilai keuntungan yang maksimum. Model pendekatan yang digunakan adalah dengan menggunakan aplikasi linear programming. Elemenelemen yang digunakan dalam model ini terdiri atas: (1) fungsi tujuan, yaitu nilai keuntungan maksimum dari usaha penangkapan udang dogol, (2) fungsi pembatas, yaitu nilai hasil tangkapan maksimum (CMSY) dan upaya penangkapan maksimum (EMSY) dan (3) koefisien input-output, yaitu nilai keuntungan tiap jenis alat tangkap untuk fungsi tujuan, nilai hasil tangkapan per unit upaya penangkapan (CPUE) per alat tangkap bagi fungsi pembatas CMSY dan indeks daya tangkap (FPI) per alat tangkap untuk fungsi pembatas EMSY.

Berdasarkan data yang ditemukan di lapangan (Lampiran 1, 2, 3, dan 4), fungsi-fungsi yang digunakan dalam penelitian ini adalah:

(1) Fungsi tujuan, yaitu memaksimumkan keuntungan usaha pemanfaatan sumber daya udang dogol (persamaan 4):

$\pi=19.120 .000 \times 1+15.598 .000 \times 2+12.570 .000 \times 3+$ $10.482 .000 \times 4$

Adapun $\pi$ adalah keuntungan yang akan dimaksimumkan, $\quad X 1$ adalah jumlah armada trammel net aktif trip mingguan, $x_{2}$ adalah jumlah armada trammel net aktif trip harian, $x 3$ adalah jumlah armada trammel net pasif dan $X 4$ adalah jumlah armada jaring dogol.

(2) Fungsi pembatas, yaitu nilai-nilai yang tidak boleh dilampaui karena kalau terlampaui maka akan merusak kelestarian sumber daya. Fungsi pembatas tersebut sebagai berikut:

\section{a. Hasil tangkapan yang lestari (CMSY).}

Suatu jenis udang di daerah tropis seperti di Indonesia dapat ditangkap oleh lebih dari satu jenis alat tangkap, sehingga hasil tangkapan gabungan dari beberapa jenis alat tangkap terhadap udang dogol harus $\leq C M S Y$. Dari hasil penelitian didapatkan potensi lestari (MSY) udang dogol di perairan Cilacap dan sekitarnya adalah 540 ton, CPUE alat tangkap trammel net aktif trip mingguan 1,2 ton/unit/tahun, CPUE alat tangkap trammel net aktif trip harian 0,3 ton/unit/tahun, CPUE alat tangkap trammel net pasif 0,1 ton/unit/tahun dan CPUE alat tangkap jaring dogol 0,3 ton/unit/tahun (Suman, 2003), dengan demikian fungsi pembatas udang dogol terhadap hasil tangkapan lestari (persamaan 5) adalah:

\section{$1,20 \times 1+0,30 \times 2+0,10 \times 3+0,30 \times 45540$}

Adapun $X 1$ adalah jumlah armada trammel net aktif trip mingguan, $X 2$ adalah jumlah armada trammel net aktif trip harian, $\times 3$ adalah jumlah armada trammel net pasif dan $X 4$ adalah armada jaring dogol.

\section{b. Upaya penangkapan yang lestari (EMSY).}

Upaya penangkapan optimum yang didapatkan dengan model surplus produksi adalah merupakan upaya penangkapan baku yang di susun dari beberapa jenis alat tangkap udang dogol, oleh karena itu harus diketahui jumlah upaya penangkapan dari masing-masing alat tangkap udang dogol. Dari hasil penelitian didapatkan upaya optimum $\left(f_{\text {opt }}\right)$ udang dogol di perairan Cilacap dan sekitarnya adalah 305 unit alat tangkap standard (trammel net aktif trip mingguan), Fishing Power Index (FPI) alat tangkap trammel net aktif trip mingguan 1, FPI alat tangkap trammel net aktif trip harian 0,25 , FPI alat tangkap trammel net pasif 0,08 ton/unit/tahun dan FPI alat tangkap jaring dogol 0,25 (Suman, 2003), maka fungsi pembatas terhadap upaya penangkapan (persamaan 6) adalah:

\section{$X 1+0,25 \times 2+0,08 \times 3+0,25 \times 4 \leq 305$}

Adapun $X 1$ adalah jumlah armada trammel net aktif trip mingguan, $X 2$ adalah jumlah armada trammel net aktif trip harian, $X 3$ adalah jumlah armada trammel net pasif dan $\times 4$ adalah armada jaring dogol.

\section{(3) Output}

Berdasarkan hasil analisis optimasi dengan Linear Programming ( $L P$ ) terhadap fungsi tujuan 
dan pembatas yang telah ditentukan sebelumnya, diperoleh hasil untuk tidak mengoperasikan alat tangkap trammel net aktif trip mingguan, trammel net aktif trip harian dan jaring dogol dalam pemanfaatan sumber daya udang dogol secara berkelanjutan. Nilai optimal jenis alat tangkap yang direkomendasikan yaitu 3.813 unit trammel net pasif (Lampiran 5). Apabila kombinasi unit optimal ini tidak dijalankan dengan seutuhnya, maka setiap perubahan kombinasi dengan memaksakan pengoperasian setiap satu unit alat tangkap trammel net aktif trip mingguan akan mengurangi pendapatan sebesar Rp. 138,10 juta per tahun, begitu juga pada pengoperasian setiap unit alat tangkap trammel net aktif trip harian akan mengurangi pendapatan sebesar Rp. 23,68 juta per tahun dan pada setiap unit pengoperasian alat tangkap jaring dogol akan mengalami penurunan pendapatan sebesar Rp. 28,79 juta per tahun (Lampiran 5).

Dengan demikian alat tangkap yang disarankan dalam pemanfaatan sumber daya udang dogol secara optimal dan berkelanjutan di perairan Cilacap adalah pengoperasian 3.813 unit alat tangkap trammel net pasif. Ditinjau dari analisis usaha, alat tangkap trammel net pasif ini juga merupakan alat tangkap yang menempati prioritas pertama dalam kriteria kelayakan usaha (NPV $=\mathrm{Rp}$. 22.684.172; Net B/C ratio $=1,26$ dan $I R R=89 \%$ ), jadi merupakan alat tangkap yang sangat terjamin keandalannya dalam keberlanjutan usaha. Kajian yang dilakukan tentang alat tangkap udang dogol yang berwawasan lingkungan di perairan Cilacap dan sekitarnya juga menunjukkan bahwa alat tangkap trammel net pasif inilah yang menempati prioritas pertama untuk dikembangkan, yang berarti alat tangkap inilah yang paling baik dalam konteks pemanfaatan sumber daya udang dogol secara berkelanjutan.

Oleh karena itu dalam jangka panjang skenario inilah yang paling optimal, karena dapat memanfaatkan sumber daya secara optimum dan lestari dengan keuntungan yang sangat tinggi yaitu Rp. 47,90 milyar per tahun. Untuk alat tangkap yang direkomendasikan dihilangkan yaitu sebanyak 188 unit alat tangkap trammel net aktif trip mingguan, 407 unit alat tangkap trammel net aktif trip harian, dan 195 unit alat tangkap jaring dogol, disarankan untuk mengalokasikan sebagai berikut: (1) seluruh alat tangkap trammel net aktif trip mingguan dialokasikan menjadi alat tangkap ikan lainnya sesuai izin peruntukannya di jalur III, (2) bagi 407 unit alat tangkap trammel net aktif trip harian dan 195 unit jaring dogol dapat dialokasikan seluruhnya menjadi 1.806 unit alat tangkap trammel net trip pasif dan (3) kekurangan 1.025 unit trammel net pasif untuk mencukupi jumlah 3.813 unit yang optimal dalam pemanfaatan udang dogol, merupakan peluang investasi di perairan Cilacap dan sekitarnya.
Strategi optimasi pemanfaatan sumber daya udang dogol yang akan diterapkan di perairan Cilacap dan sekitarnya terlihat menjamin pemanfaatan udang dogol secara berkelanjutan yang sesuai dengan kriteria yang dikemukakan Monintja (2000) sebagai berikut:

(1) Hasil tangkapan tidak melebihi jumlah yang boleh dimanfaatkan, yang terealisasi dari tingkat produksi yang tidak boleh melebihi potensi lestari sebesar 540 ton per tahun.

(2) Menggunakan bahan bakar lebih sedikit, di mana hal ini tercermin dari penghematan bahan bakar sekitar 56\% (15 liter) per unit per hari. Pada kondisi sekarang rata-rata biaya bahan bakar adalah sekitar Rp. 60.000 dan setelah kebijakan diproyeksikan hanya memerlukan biaya sekitar Rp.30.000.-.

(3) Secara hukum alat tangkap legal, di mana seluruh unit armada yang diproyeksikan adalah sesuai untuk beroperasi di jalur penangkapan I, yang merupakan daerah penangkapan udang. Pada saat ini sekitar 188 unit armada penangkapan udang dogol yaitu alat tangkap trammel net aktif trip mingguan adalah illegal karena izinnya di jalur III, tetapi pada kenyataannya beroperasi di jalur I karena komoditas yang menjadi tujuan penangkapannya berada di jalur 1. Dalam strategi pemanfaatan yang diusulkan armada ini dihapuskan dan sebagai alternatif untuk armada ini diubah menjadi armada penangkapan ikan di jalur III.

(4) Investasi yang dibutuhkan rendah, yang tergambar dari turunnya biaya investasi sekitar $46 \%$ (Rp. 14 juta) dari kondisi yang ada sekarang. Proyeksi dalam strategi ini setiap unit armada membutuhkan biaya investasi sebesar Rp. 16,70 juta, di mana biaya investasi sebelumnya mencapai biaya sebesar Rp. 30,70 juta per unit armada penangkapan udang dogol.

(5) Produk mempunyai pasar yang baik, terutama untuk tujuan ekspor. Dengan strategi ini maka proses produksi telah memperhatikan kaidahkaidah keberlajutan dan berwawasan lingkungan, dan dengan demikian akan menjamin diterimanya produk penangkapan ini di pasar luar negeri.

\section{KESIMPULAN DAN SARAN}

1. Alat tangkap udang dogol di perairan Cilacap dan sekitarnya dikategorikan menjadi 4 yaitu alat tangkap trammel net aktif trip mingguan, alat tangkap trammel net aktif trip harian, alat tangkap trammel net pasif, dan jaring dogol.

2. Optimasi pemanfaatan sumber daya udang dogol di perairan Cilacap dalam rangka menjamin kelestariannya adalah dengan mengoperasikan 
3.813 unit alat tangkap trammel net pasif per tahun dan keuntungan yang di peroleh dari penerapan pola pemanfaatan ini diperkirakan sebesar $R p$ 47,90 milyar per tahun.

3. Alat tangkap yang direkomendasikan untuk tidak dioperasikan yaitu sebanyak 188 unit alat tangkap trammel net aktif trip mingguan, 407 unit alat tangkap trammel net aktif trip harian, dan 195 unit alat tangkap jaring dogol. Agar tidak ada gejolak sosial maka seluruh alat tangkap trammel net aktif trip mingguan disarankan diubah menjadi alat tangkap pelagis besar sesuai dengan izin peruntukannya, 407 unit alat tangkap trammel net aktif trip harian dan 195 unit jaring dogol dialokasikan seluruhnya menjadi 1.806 unit alat tangkap trammel net trip pasif. Kekurangan 1.025 unit trammel net pasif untuk mencukupi jumlah 3.813 unit yang optimal dalam pemanfaatan udang dogol, merupakan peluang investasi di perairan Cilacap dan sekitarnya.

4. Penerapan strategi optimasi pemanfaatan sumber daya udang dogol di perairan Cilacap dan sekitarnya dapat menjamin kelestarian sumber daya dan meningkatkan kesejahteraan nelayan, di samping itu dapat mengintegrasikan aspek ekonomi dan sosial sebagai dimensi dari perikanan yang berkelanjutan.

\section{DAFTAR PUSTAKA}

Gunadi, W. 1981. Studi pendahuluan tentang penangkapan udang dengan trammel net di perairan Cilacap. Karya IImiah pada Fakultas Perikanan, IPB, Bogor: 68 hal.

Monintja, D.R. 2000. Prosiding pelatihan untuk pengelolaan wilayah pesisir terpadu. Pusat Kajian Sumber Daya Pesisir dan Lautan, IPB Bogor, hal.: 45-57.

Naamin, N. 1972. Perkembangan perikanan udang di perairan Cilacap dan Pangandaran. Laporan Penelitian Perikanan Laut No. 1: 59-79.

Naamin, N. 1978. Perkembangan perikanan udang di Indonesia. Prosiding Seminar Ke-Il Perikanan Udang, hal.: 55-65.

Soekartawi, 1995. Linear programming. Teori dan aplikasinya khusus dalam bidang pertanian. Penerbit Raja Grafindo Persada, Jakarta.

Suman, A. 2003. Pola pemanfaatan sumber daya udang dogol (Metapenaeus ensis de Haan) secara berkelanjutan di perairan Cilacap dan sekitarnya.

Supranto, J. 1988. Riset operasi untuk pengambilan keputusan. Cetakan pertama. Universitas Indonesia, Jakarta.

Van Zalinge, N.P. \& N. Naamin. 1975. The Cilacap based trawl fishery for shrimp along the south coast of Java. Laporan Penelitian Perikanan Laut No. 2: 1-15. 
Lampiran 1. Analisis usaha alat tangkap trammel net aktif trip mingguan di perairan Cilacap dan sekitarnya Appendix 1. Financial analysis of active trammel net in weekly trip in Cilacap and adjacent waters

\section{Komponen Biaya}

Biaya Investasi:

- Perahu

:Rp. 38.600.000.-

- Mesin

:Rp. 12.600.000.-

- Alat tangkap

:Rp. 8.500.000.-

Total investasi

: Rp. 59.700.000.-

\section{Biaya Operasi:}

- Solar

:Rp. 825.000.-

- Oli

:Rp. 70.000.-

- Minyak tanah

:Rp. 14.000.-

- Es balok

:Rp. 280.000.-

- Konsumsi

Total biaya operasi per trip

:Rp. 500.000.-

Total biaya operasi per tahun

:Rp. 1.689.000.-

:Rp. 67.560.000.-

Biaya Penyusutan:

- Perahu

:Rp. $\quad 3.300 .000$.-

- Mesin

:Rp. 3.600.000.-

- Alat tangkap

Total biaya penyusutan

:Rp. 8.500.000.-

:Rp. 15.400.000.-

\section{Biaya Perawatan:}

- Perahu

- Mesin

- Alat tangkap

Total biaya perawatan

:Rp. 4.000.000.-

:Rp. 1.200.000.-

:Rp.

:Rp. 5.200.000.-

Hasil usaha per tahun:

- Hari operasi rata-rata per trip : 7 hari

- Jumlah operasi rata-rata per tahun : 40 trip

- Jumlah ABK

- Hasil tangkapan rata-rata per trip

: 7 orang

- Hasil penjualan rata-rata per kg

$: 70 \mathrm{~kg}$

: Rp.

- Penerimaan rata-rata per tahun

Rp. 140.000.000.-

- Bagi hasil

- Retribusi

: Rp. 25.720.000.-

: Rp. 7.000.000.-

Rekapitulasi:

- Penerimaan per tahun

: Rp. 140.000.000.-

- Biaya total per tahun

- Pendapatan bersih per tahun 
Lampiran 2. Analisis usaha alat tangkap trammel net aktif trip harian di perairan Cilacap dan sekitarnya Appendix 2. Financial analysis of active trammel net in daily trip in Cilacap and adjacent waters

\section{Komponen Biaya}

\section{Biaya Investasi:}

- Perahu

- Mesin

- Alat tangkap

Total investasi

Biaya Operasi:

- Solar

- Oli

- Minyak tanah

- Es balok

- Konsumsi

Total biaya operasi per trip

Total biaya operasi per tahun

Biaya Penyusutan:

- Perahu

- Mesin

- Alat tangkap

Total biaya penyusutan

Biaya Perawatan:

- Perahu

- Mesin

- Alat tangkap

Total biaya perawatan

Hasil usaha per tahun:

- Hari operasi rata-rata per trip

- Jumlah operasi rata-rata per tahun

- Jumlah ABK

- Hasil tangkapan rata-rata per trip

- Hasil penjualan rata-rata per kg

- Penerimaan rata-rata per tahun

- Bagi hasil

Rekapitulasi:

- Penerimaan per tahun

- Biaya total per tahun

- Pendapatan bersih per tahun
:Rp. 12.800.000.-

:Rp. 7.800.000.-

:Rp. 3.200.000.-

: Rp. 23.800.000.-

: Rp. $\quad 45.000 .-$

:Rp. $\quad 8.000$.-

:Rp. 2.400.-

:Rp. 5.000.-

:Rp. 28.000.-

:Rp. 88.400.-

:Rp. 14.144.000.-

:Rp. 900.000.-

:Rp. 1.100.000.

:Rp. 1.400.000.-

: Rp. 3.400.000.-

:Rp. $\quad 150.000 .-$

:Rp. $\quad 500.000$.-

:Rp. 1.000.000.-

:Rp. 1.650.000.-

: 1 hari

: 160 trip

4 orang

: $7 \mathrm{~kg}$

:Rp.

45.000.-

: Rp. 50.400.000.-

: Rp. 15.608.000.-

: Rp. 50.400.000.-

: Rp. 34.802.000.-

: Rp. 15.598.000.- 
Lampiran 3. Analisis usaha alat tangkap trammel net pasif di perairan Cilacap dan sekitarnya Appendix 3. Financial analysis of passive trammel net in Cilacap and adjacent waters

\section{Komponen Biaya}

Biaya Investasi:

- Perahu

:Rp. 7.900.000.-

- Mesin

:Rp. 5.700.000.=

- Alat tangkap

:Rp. 3.100.000.-

Total investasi

:Rp. 16.700.000."

\section{Biaya Operasi:}

- Bensin

: Rp. 26.400.-

- Oli

- Es balok

- Konsumsi

:Rp. 3.000.-

Total biaya operasi per trip

$\begin{array}{lr}R p & 4.000 .-\end{array}$

Total biaya operasi per tahun

: Rp. 53.400.-

:Rp. 10.680.000.-

Biaya Penyusutan:

- Perahu

:Rp. $\quad 600.000 .-$

- Mesin

:Rp. 500.000.-

- Alat tangkap

: Rp. 2.200.000.-

Total biaya penyusutan

: Rp. 3.300.000.-

\section{Biaya Perawatan:}

- Perahu

:Rp. 200.000.-

- Mesin

:Rp. 100.000.-

- Alat tangkap

:Rp. 150.000.-

Total biaya perawatan

:Rp. 450.000.

Hasil usaha per tahun:

- Hari operasi rata-rata per trip

- Jumlah operasi rata-rata per tahun

1 hari

- Jumlah ABK

- Hasil tangkapan rata-rata per trip

200 trip

: 2 orang

- Hasil penjualan rata-rata per kg

$5 \mathrm{~kg}$

: Rp.

45.000.-

- Penerimaan rata-rata per tahun

- Bagi hasil

: Rp. 45.000.000.-

: Rp. 18.000.000.-

Rekapitulasi:

- Penerimaan per tahun

Rp. 45.000.000.=

- Biaya total per tahun

- Pendapatan bersih per tahun

: Rp. 32.430.000..

:Rp. 12.570.000.- 
Lampiran 4. Analisis usaha alat tangkap jaring dogol di perairan Cilacap dan sekitarnya Appendix 4. Financial analysis of dogol net in Cilacap and adjacent waters

\section{Komponen Biaya}

Biaya Investasi:

- Perahu

- Mesin

- Alat tangkap

Total investasi

Biaya Operasi:

- Bensin

- Oli

- Konsumsi

Total biaya operasi per trip

Total biaya operasi per tahun

Biaya Penyusutan:

- Perahu

- Mesin

- Alat tangkap

Total biaya penyusutan

Biaya Perawatan:

- Perahu

- Mesin

- Alat tangkap

Total biaya perawatan

Hasil usaha per tahun:

- Hari operasi rata-rata per trip

- Jumlah operasi rata-rata per tahun

- Jumlah ABK

- Hasil tangkapan rata-rata per trip

- Hasil penjualan rata-rata per kg

- Penerimaan rata-rata per tahun

- Bagi hasil

Rekapitulasi:

- Penerimaan per tahun

- Biaya total per tahun

- Pendapatan per tahun
:Rp. 7.600.000.-

:Rp. 11.600.000.-

:Rp. 3.500.000.-

: Rp. 22.700.000.-

: Rp. $\quad 33.750 .-$

:Rp. 3.000.-

:Rp. 25.000.-

:Rp. 61.750.-

:Rp. 9.880.000.-

:Rp. $\quad 500.000$.-

:Rp. 1.800.000.-

:Rp. $\quad 900.000$.-

:Rp. 3.200.000.-

:Rp. 150.000.-

:Rp. 200.000.-

:Rp. 200.000.-

:Rp. 550.000.-

: 1 hari

: 160 trip

: 4 orang

$: 7 \mathrm{~kg}$

: Rp. 30.000.-

: Rp. 33.600.000.-

: Rp. 9.488.000.-

: Rp. 33.600.000.-

:Rp. 23.118.000.-

:Rp. 10.482.000.- 
Lampiran 5. Hasil perhitungan dengan program linear di perairan Cilacap dan sekitarnya Appendix 5 . Result of calculated by linear program in Cilacap and adjacent waters

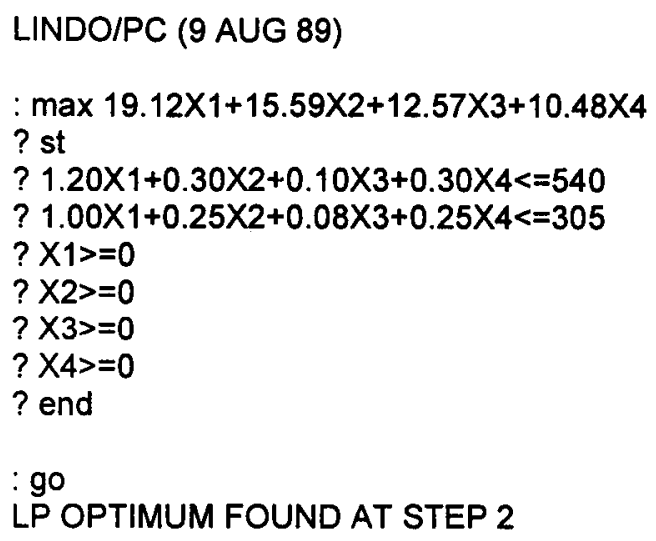

\begin{tabular}{ccc}
\hline VARIABLE & VALUE & REDUCED COST \\
\hline X1 & .00 & 138.01 \\
X2 & .00 & 23.68 \\
X3 & 3812.50 & .00 \\
X4 & .00 & 28.79 \\
\hline \multicolumn{4}{c}{} & \\
\hline ROW & SLACK OR SURPLUS & DUAL PRICES \\
\hline 2$)$ & 158.75 & .00 \\
$3)$ & .00 & 157.13 \\
$4)$ & .00 & .00 \\
$5)$ & .00 & .00 \\
$6)$ & 3812.50 & .00 \\
$7)$ & .00 & .00 \\
\hline
\end{tabular}

NO. ITERATIONS $=2$

DO RANGE (SENSITIVITY) ANALYSIS?

\section{$?$ yes}

RANGES IN WHICH THE BASIS IS UNCHANGED:

\begin{tabular}{|c|c|c|c|}
\hline \multicolumn{4}{|c|}{ OBJ COEFFICIENT RANGES } \\
\hline VARIABLE & $\begin{array}{l}\text { CURRENT } \\
\text { COEF }\end{array}$ & $\begin{array}{l}\text { ALLOWABLE } \\
\text { INCREASE }\end{array}$ & $\begin{array}{l}\text { ALLOWABLE } \\
\text { DECREASE }\end{array}$ \\
\hline $\mathrm{X} 1$ & 19.12 & 138.01 & INFINITY \\
\hline $\mathrm{x} 2$ & 15.59 & 23.68 & INFINITY \\
\hline $\mathrm{x} 3$ & 12.57 & INFINITY & 7.58 \\
\hline$\times 4$ & 10.48 & 28.79 & INFINITY \\
\hline \multicolumn{4}{|c|}{ RIGHTHAND SIDE RANGES } \\
\hline ROW & $\begin{array}{l}\text { CURRENT } \\
\text { RHS }\end{array}$ & $\begin{array}{l}\text { ALLOWABLE } \\
\text { INCREASE }\end{array}$ & $\begin{array}{l}\text { ALLOWABLE } \\
\text { DECREASE }\end{array}$ \\
\hline 2 & 540.00 & INFINITY & 158.75 \\
\hline 3 & 305.00 & 127.00 & 305.00 \\
\hline 4 & .00 & .00 & INFINITY \\
\hline 5 & .00 & .00 & INFINITY \\
\hline 6 & .00 & 3812.50 & INFINITY \\
\hline 7 & .00 & .00 & INFINITY \\
\hline
\end{tabular}


